\title{
S2 Figure
}

(a)

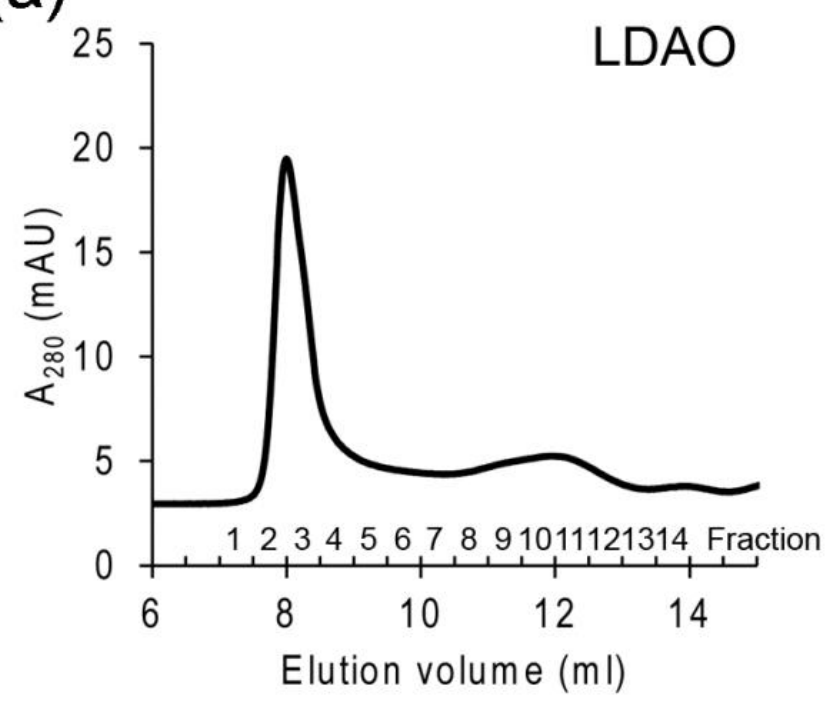

(b)

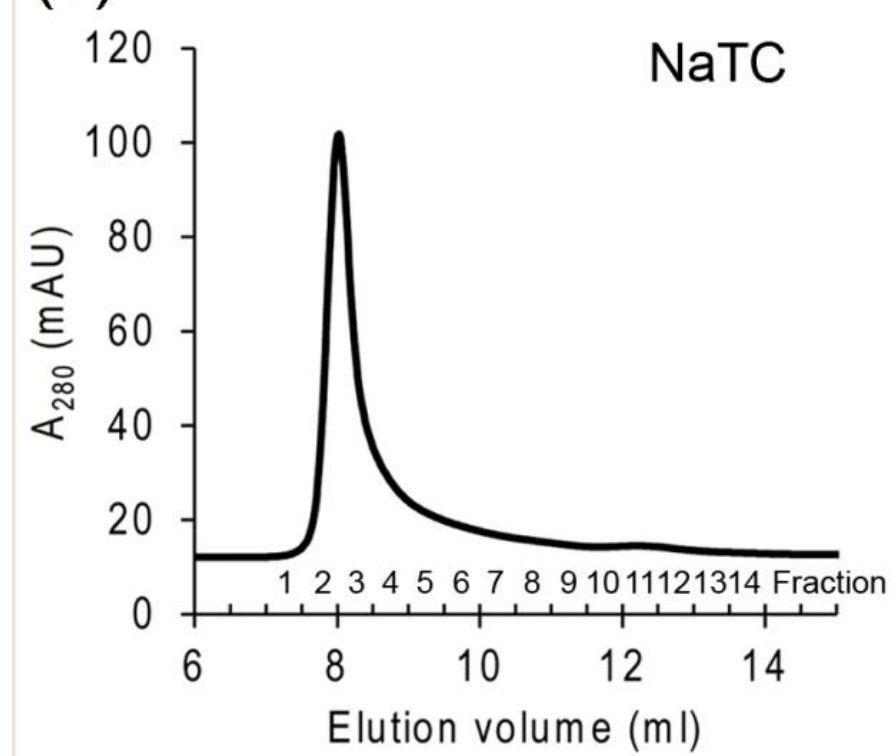

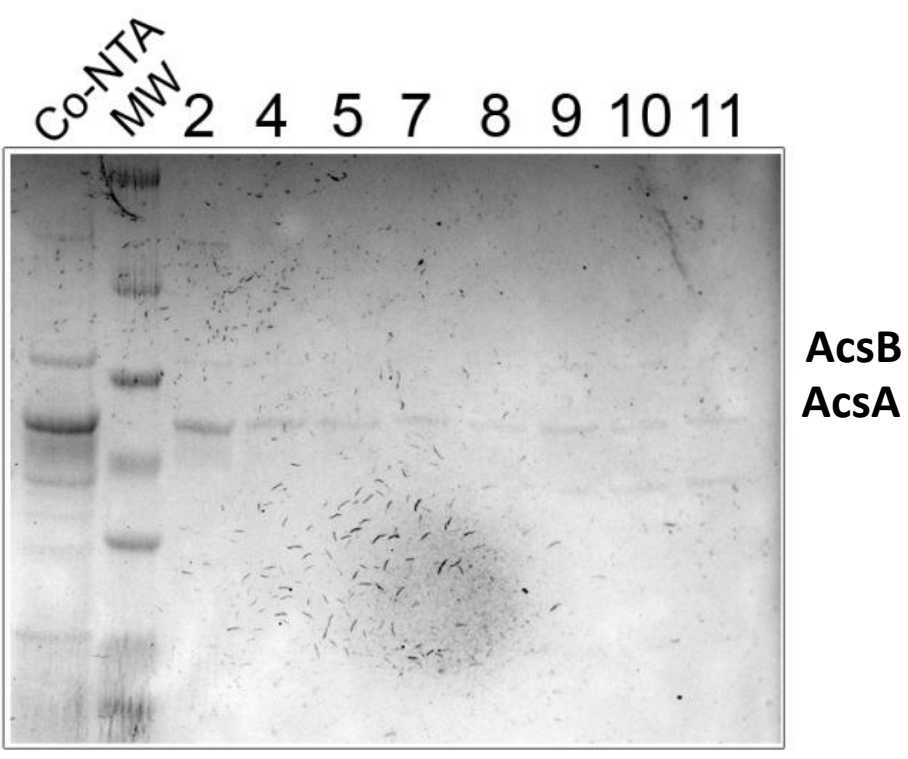

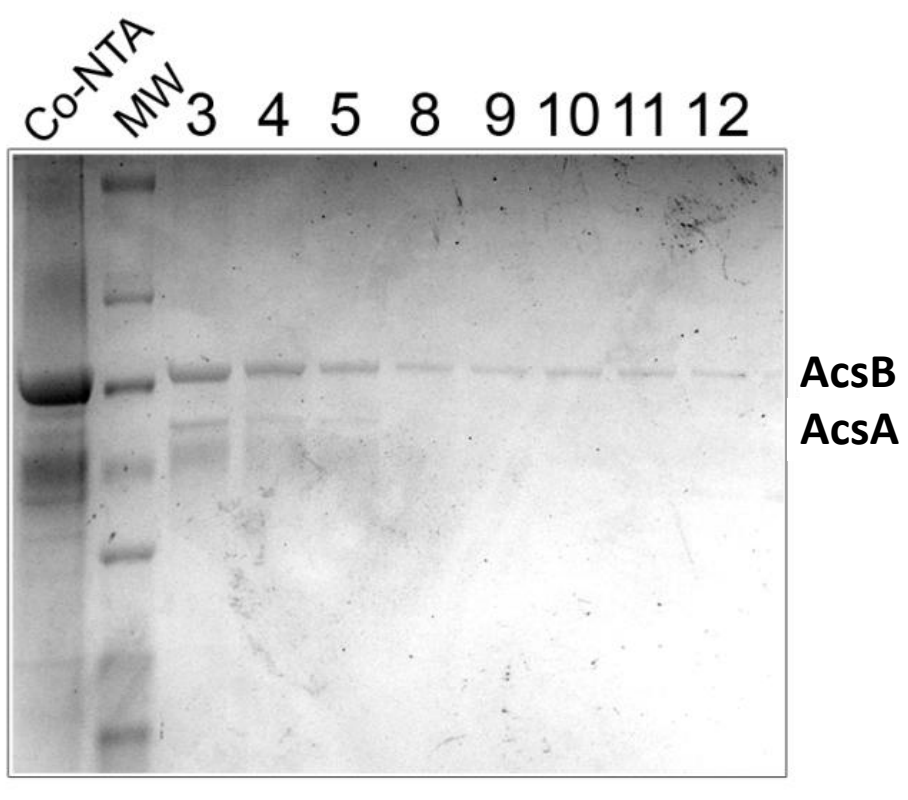

